\title{
Simultaneous effect of habitat and age on reproductive success of Imperial Eagles (Aquila heliaca) in Hungary
}

\author{
Márton Horváth ${ }^{1 *}$, Tamás Szitta ${ }^{1}$, János Bagyura $^{1}$, Imre Fatér ${ }^{1}$, \\ GÁbOr FirmÁnSZKY ${ }^{1} \&$ CSABA MoskáT ${ }^{2}$
}

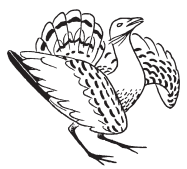

Márton Horváth, Tamás Szitta, János Bagyura, Imre Fatér, Gábor Firmánszky \& Csaba Moskát 2014. Simultaneous effect of habitat and age on reproductive success of Imperial Eagles (Aquila heliaca) in Hungary. - Ornis Hungarica 22(1): 57-68. was observed in East Hungary from mountainous habitat into lowlands from 1989 onwards. Here the population markedly increased from 2 to 59 breeding pairs by 2006, while the mountainous population remained more or less stable with 12-17 breeding pairs. At the beginning of the expansion process the nearest neighbour distances between breeding pairs was lower in the mountains than in the lowlands, but presently they are similar, indicating a saturation process in the lowland areas, but no density dependence was revealed on breeding success. During the study period a higher ratio of non-adult pairs was observed in the lowland territories $(49 \%)$ than in the mountains $(22 \%)$. We found that both age and habitat influenced breeding success. We also found that age-effect was significant on success rate (i.e. the ratio of pairs that produce at least one chick), while habitat-effect was more evident on fledging success (i.e. the number of fledglings per productive pair). The overall productivity (i.e. number of fledglings per breeding pair) was affected primarily by the age of the pairs, but the interaction term of age $\mathrm{x}$ habitat also was significant. We suppose that better feeding possibilities (closer foraging areas and larger prey density) could explain the higher fledging success in the lowlands. We also predicted that pairs inhabiting agricultural areas in the lowlands will have a reduced success rate due to higher human disturbance, together with an age effect of the breeding pairs. Therefore adult pairs probably can habituate to disturbance even if it happens in the close vicinity of their nesting sites.

Keywords: population dynamics, breeding success, territory, raptor

Összefoglalás A parlagi sas kelet-magyarországi elterjedési területe jelentős mértékben kiterjedt az Alföld irányába 1989-től 2006-ig, amely során az alföldi állomány 2-ről 59 párra emelkedett, míg a hegyvidéki állomány viszonylag stabil maradt, és 12-17 pár között változott. A terjeszkedési folyamat elején, a hegyvidéki élőhelyeken kisebb volt a párok közötti legközelebbi szomszéd távolság, mint síkvidéken, azonban ez 2006-ra kiegyenlítődött. Denzitásfüggő hatást egyelőre nem lehet megfigyelni az átlagos költési siker alakulásában. A vizsgálati időszakban, a síkvidéki territóriumokban magasabb volt az átszíneződő fiatal madarak aránya (49\%), mint a hegyvidékiekben (22\%). A költő madarak korának és az élöhelynek a költési sikerre gyakorolt együttes hatását vizsgáltuk. Azt találtuk, hogy a költő madarak kora inkább a költések sikerességi arányát (sikeres párok/összes költő pár) befolyásolta, míg az élőhely inkább a kirepülési sikerre (kirepült fiókák száma/sikeres pár) volt hatással. Összességében a produktivitást (kirepült fiókák száma/összes költő pár) alapvetően a madarak kora befolyásolta, de a kor és az élőhely interakciója is szignifikáns hatással volt. Az adatok alátámasztják azt a predikciónkat, miszerint a síkvidéki területek jobb táplálkozási lehetőségei (közelebbi táplálkozó területek és nagyobb zsákmány-denzitás) magasabb költési sikert eredményezhetnek. A másik predikciónk, miszerint a síkvidéki párok sikerességi aránya alacsonyabb a jelentősebb emberi zavarás miatt, csak részben igazolódott. Bár ez a trend megfigyelhető volt az adatokban, de csak a párok korával interakcióban volt szignifikáns a különbség. Ezért úgy gondoljuk, hogy a tapasztalt öreg madarak megfelelő mértékben hozzá tudnak szokni az emberi jelenléthez a fészkek közvetlen környezetében is. 


\begin{abstract}
${ }^{1}$ Magyar Madártani és Természetvédelmi Egyesület (MME BirdLife Hungary), 1121 Budapest, Költö utca 21., Hungary,e-mail:horvath.marton@mme.hu

${ }_{2}^{2}$ MTA-ELTE-MTM Ecology Research Group, c/o Biological Institute, Eötvös Loránd University, 1117 Budapest, Pázmány Péter sétány 1/C., Hungary and Hungarian Natural History Museum, 1088 Budapest, Baross utca 13., Hungary *corresponding author
\end{abstract}

\section{Introduction}

Biotic and abiotic environmental variables, like topography, vegetation, prey availability, predators, and competitors, influence habitat selection in birds (Hildén 1965, Cody 1985, Wiens 1989). Habitat selection of larger-sized raptor species typically depends on the availability of nesting sites and feeding areas (Janes 1985, Tapia et al. 2008). If raptors choose an optimal nesting habitat, they increase their reproductive success by decreasing the risk of predation (Sergio et al. 2007), avoiding competitors (Katzner et al. 2003), or human disturbance (López-López et al. 2007). Another important component, which is connected to habitat quality and has main effects on raptors' reproductive success, is prey-availability in feeding areas, like density and quality of prey (Penteriani et al. 2006, Sergio et al. 2006) and distance of foraging areas from nesting sites. Distance between nests and feeding areas play a key role when birds optimize their energy expenditure for maximizing their fitness (Cowie 1977). The quality of nesting sites and feeding areas seems to be important factors, which mainly affect the viability of raptor populations (Krüger $e t$ al. 2002). Besides the direct and indirect effects of habitat quality, density dependence (Ferrer \& Donazar 1996, Ferrer et al. 2006, Ferrer \& Penteriani 2008) and age of breeding birds (Steenhof et al. 1983, Balbontín et al. 2003, Ferrer \& Bisson 2003, Penteriani et al. 2003, Margalida et al. 2007) are known to have crucial effects on breeding success. The effect of age can be especial- ly important in instable populations, where the relative frequency of non-adult breeders increases, due to lack of adult breeders in comparison to available habitats (Ferrer et al. 2004).

Many of the large-sized raptors are among the threatened birds in the world (Del Hoyo et al. 1995). The Eastern Imperial Eagle (Aquila heliaca) has a wide distribution area in the forest-steppe zone of the Palearctic region, it breeds from western Austria, Czech Republic, Slovakia and Hungary throughout eastern Europe and Siberia to the Baikal Lake in Russia. Nevertheless its distribution is scattered and the species is globally threatened, as its world population consists only a few thousand breeding pairs (Del Hoyo et al. 1995, BirdLife International 2013).

Throughout its distribution area Imperial Eagles are connected to open foraging habitats, where its medium-sized mammal or bird preys are available (Del Hoyo et al. 1995). In several regions they are breeding in forested mountains, mostly due to persecution or the lack of suitable trees in the nearby open plain habitats (Petrov et al. 1996, Karyakin et al. 2008). We have no reliable data about the breeding distribution of Imperial Eagles in Hungary prior to the 1970's, although all early literature since the end of the $19^{\text {th }}$ century mention it as a rare breeder of the Hungarian mountains, and only scarce observations are available from the Great Hungarian Plain (Vasvári 1938). The Hungarian population of the Eastern Imperial Eagle presumably reached its historical minimum with only 15-25 breeding pairs in mountainous forests by 
the 1980's. During the last two decades an unexpected increase of the population was observed and by 2009 the Hungarian population already exceeded 100 pairs (Horváth et al. 2011). In parallel the species also expanded its breeding range from mountain forests to lowland agricultural areas. Twothirds of Hungary consists of such agricultural habitats, so there is a chance for further area expansion of Imperial Eagles in the near future.

In the present study we investigated the factors affecting reproductive success of the largest subpopulation of Imperial Eagles in Central Europe during its area expansion. As the population is still exponentially increasing and probably is under the saturation point, we predicted that recently there is no significant density dependent effect on productivity. We also hypothesized that both age of the breeding birds and habitat type affect the reproductive success of Imperial Eagles. On one hand we predicted that the probability of successful breeding in the lowland areas is lower than in the mountains, due to a higher level of human disturbance connected to intensive agriculture and higher density of urbanized areas and infrastructure. On the other hand we also predicted that fledging success is higher in lowland areas where Brown Hares (Lepus europaeus), the main prey species of Imperial Eagles (Horváth et al. 2010), are more abundant and open foraging areas are closer to the nesting sites.

\section{Methods}

\section{Study area}

The study was conducted in the central part of the Great Hungarian Plain and adjacent low mountains $\left(46^{\circ} 30^{\prime}-48^{\circ} 30^{\prime} \mathrm{N} 1^{\circ} 50^{\prime}\right.$ ' $21^{\circ} 40^{\prime} \mathrm{E}, 20000 \mathrm{~km}^{2}$ ). Most parts of the study area are lowlands between 80-100 $\mathrm{m}$ a.s.1., like the Jászság, Heves, Borsod, Nagykunság and Békés Plains, which lie in the wide valley of the Tisza River and its tributaries. The Plain is mostly covered by intensive agricultural fields and small remnants of grasslands, which are scattered by small groups of poplars (Populus spp.) and black locust trees (Robinia pseudoacacia). The northern border of the Plain is formed by the Mátra, Bükk and Zemplén Mountains (200-1014 m a.s.1.) which are predominantly covered by oak (Quercus petraea, Q. cerris, Q. pubescens), beech (Fagus sylvatica) and introduced pine (Pinus silvestris, P. nigra, Larix decidua) forests.

\section{Data collection}

Breeding territories of the Eastern Imperial Eagle were monitored by a well-trained network of observers, organised by MME BirdLife Hungary and Hungarian national park directorates since 1980 (Haraszthy et al. 1996, Bagyura et al. 2002, Horváth et al. 2011). In the present study we analysed data collected between 1989 and 2006, when monitoring covered all potential breeding territories. At the beginning of each breeding season (February-March) all previously identified territories and their surroundings up to $10 \mathrm{~km}$ were visited in order to locate active nests of Imperial Eagle pairs. Afterwards, during the whole breeding season (from April to August) all active nests were controlled for at least once per month to determine breeding success or failure in each breeding stage (incubation, small-, medium- and large-chick and fledging periods). Observations were carried out by spotting scopes $(20-60 \times)$ from a distance of 0.5-1.5 $\mathrm{km}$ to avoid unnecessary disturbance of the 
birds (González et al. 2006a). We checked nest content once during the breeding season to monitor the exact number of alive or dead offspring, when the chicks were 4-7 weeks old (mostly between 10-25 June), or when the breeding failed. Locations of the nests were identified with GPS and stored in a GIS database together with other breeding parameters.

During this 18 -year study 645 breeding attempts were monitored in 89 breeding territories. By definition two nests belonged to the same territory if they were closer than $7.3 \mathrm{~km}$ to each other (the average nearest neighbour distance in 2006) and not more than one territorial pair used them within the same year (Ferrer \& Bisson 2003). Two different breeding habitat types were used by the species in the study area, such as mountainous forests and small patches of trees in open agricultural landscape of the lowlands. The breeding attempts were classified into the two breeding habitat types based on the $200 \mathrm{~m}$ contour line. This contour line also separated the open and forested nest sites without any notable overlap, as all $(100 \%)$ of the 262 'mountainous', but only eight (2.1\%) out of the 383 'lowland' breeding attempts were in forested habitats. Subsequent breeding attempts of the same territory were usually within the same habitat type (15 pure mountainous and 67 pure lowland territories). However, in seven territories the pairs switched between the two habitat types. These mixed territories were also classified into that habitat type where more breeding attempts occurred and only the average of these breeding attempts were used for territorial comparisons.

Members of the breeding pairs were categorised during the population monitoring as 'adult' or 'non-adult' birds, as these two age classes can be distinguished relative- ly easily in the field based on plumage characteristics. Similarly to the Spanish Imperial Eagle (Ferrer et al. 2004, González et al. 2006b) and other large eagles (Steenhof et al. 1983, Balbontín et al. 2003), Eastern Imperial Eagles regularly breed already in their $3^{\text {rd }}-5^{\text {th }}$ calendar year, before they accomplish their moult to the dark brown adult plumage (Katzner et al. 2006, authors own data). Nonetheless, the exact age determination of non-adult eagles needs substantial experience (Forsman 1999). A breeding pair was classified as 'non-adult' if at least one member of the pair was in non-adult plumage, and as ' $a d u l t$ ' if both members were in adult plumage. In 25 cases ( $4 \%$ of breeding attempts) the age class of both birds could not be identified, therefore these were typically excluded from calculations.

\section{Statistical analyses}

To avoid pseudoreplication that would arise if each breeding attempt would be included separately, we used territories as sampling units in the comparative analyses (c.f. Steenhof 1987, Ferrer \& Bisson 2003, Penteriani et al. 2003, Sergio \& Newton 2003, Margalida et al. 2007), and annual mean values for analysing temporal trends during the study period (Balbontín et al. 2003, Ferrer \& Bisson 2003). Breeding success was measured with three variables (Steenhof 1987, Balbontín et al. 2003), such as the number of fledglings per nesting pair (referred to as productivity in the followings), the frequency of nesting pairs that fledged at least one chick (referred to as success rate in the followings), and the number of fledglings per successful nesting pairs (referred to as fledging success in the followings). For the calculation of mean values for territories we controlled for year effect by subtracting 
annual means from the original breeding success data (Ferrer \& Bisson 2003, Penteriani et al. 2003). We excluded those territories from the analyses where less than three breeding attempts occurred. Density dependence was estimated by nearest neighbour distances (NND) (Newton et al. 1977, Penteriani et al. 2003).

Normal distribution of variables was tested prior applying parametric tests, and in case to significant deviation non-parametric tests were used. Generalized Linear Models were used to test simultaneous effect of habitat type and age of birds on breeding success variables, and the interaction of the two factors were removed from the model, if it had no significant effect. All statistical tests were two-tailed and significance level was set at $P<0.05$. Data are presented as mean \pm SD. Distances were measured by ArcMap ( software (ESRI Inc., version 9.0). Analyses were executed by the SPSS programmes package (SPSS Co., ver. 17).

\section{Results}

\section{Temporal variation of population parameters}

Altogether 79 new territory occupancies (i.e. when a breeding pair appeared in a territory where no breeding attempt was recorded in the previous year) were observed during the study period, with only $12(15 \%)$ located in the mountains, while the rest of the new territories $(85 \%)$ appeared in the lowland. We identified the age of both breeding birds in 70 cases, from which 57 (81\%) new territories were occupied by non-adults. This frequency was significantly different from the $24 \%$ value of non-adults, which was observed among the other 550 breeding attempts $\left(\chi^{2}=123.416\right.$, $P<0.001)$.

Population size increased markedly in the lowland (annually increased by $25 \%$; $F=281.401, d f=1,16, P<0.001$ ), and also in the mountains, although here the trend was not so sharp and not constant (annually increased by $5 \% ; F=5.859, d f=1,16, P$ $=0.033$ ) (Figure 1a). In parallel with the increasing population size the NND decreased in the lowland $(F=22.445, d f=1,16, P<$ 0.001 ), but did not change significantly in the mountains $(F=2.747, d f=1,16, P=$ 0.117 ) (Figure $1 b$ ). The frequency of nonadult pairs in the breeding population increased in the lowlands $(F=7.401, d f=$ $1,16, P=0.015)$ and decreased in the mountains $(F=5.379, d f=1,16, P=0.034)(F i-$ gure $1 c$ ). None of the breeding success variables showed significant trends in the two habitat types during the study period (productivity: $F=0.148, d f=1,16, P=0.705$ for mountains and $F=0.108, d f=1,16, P$ $=0.747$ for the lowland) (Figure 2a); success rate: $F=0.401, d f=1,16, P=0.535$ for the mountains and $F=0.613, d f=1,16, P=$ 0.445 for the lowland, (Figure 2b); fledgling success: $F=0.041, d f=1,16, P=0.842$ for the mountains and $F=0.718, d f=1,16, P=$ 0.409 for the lowland) (Figure 2c).

\section{Density dependence}

Territory averages of NND was significantly lower in mountainous than in lowland territories $(6.6 \pm 3.2 \mathrm{~km}$ and $12.7 \pm 14.5$ $\mathrm{km}$, respectively; Mann-Whitney U-test, $Z=-2.728, P=0.006$ ), although the difference became non-significant, or even reversed by the last years of the study period $(8.4 \pm 4.8 \mathrm{~km}$ and $7.1 \pm 4.3 \mathrm{~km}$ in 2006 , respectively; Mann-Whitney U-test, $\mathrm{Z}=$ $-0.722, \mathrm{P}=0.470)$. We did not find any sig- 

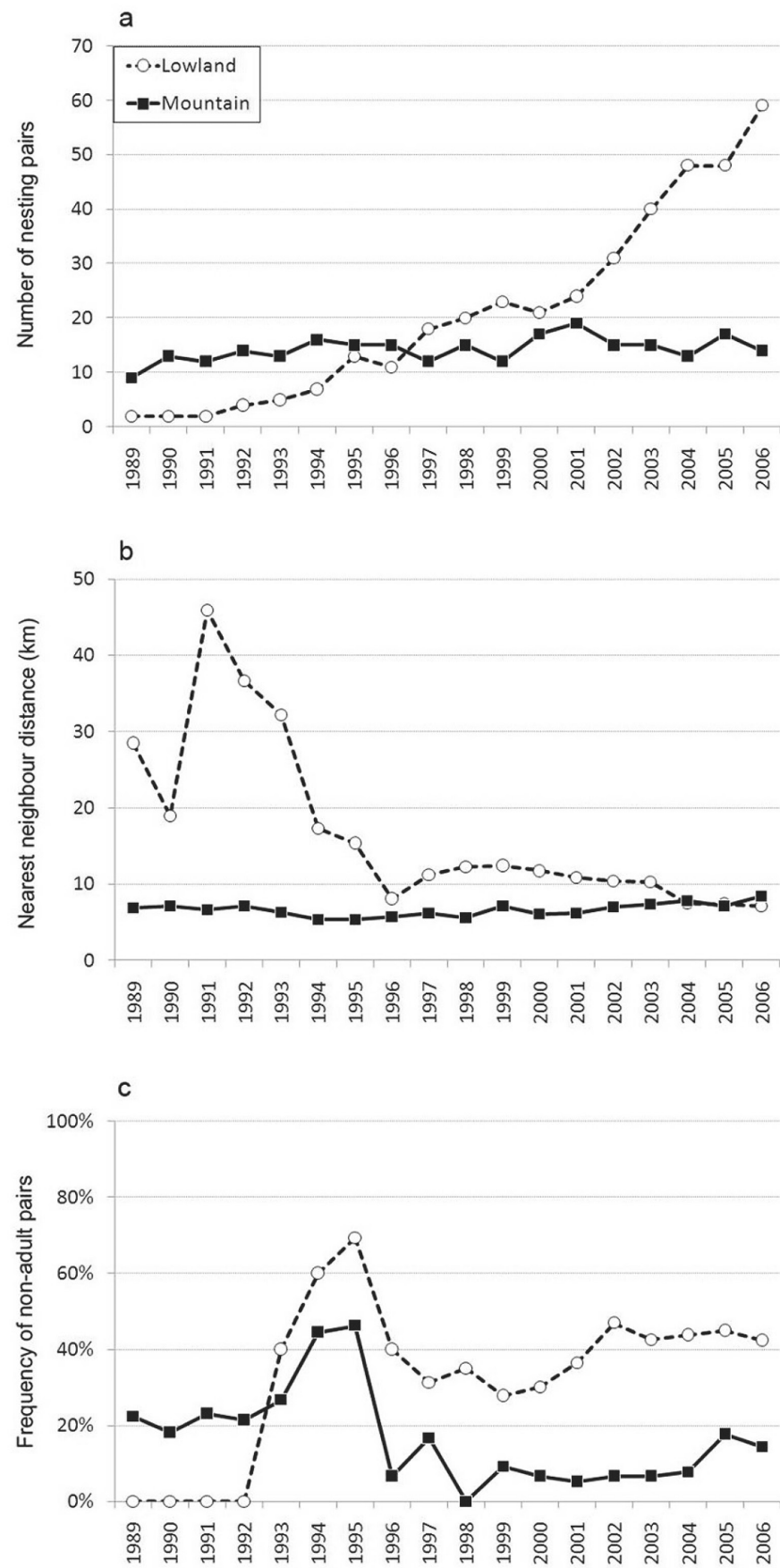

Figure 1. Changes in number of nesting pairs (a), nearest neighbour distance (b) and frequency of non-adult pairs (c) of Eastern Imperial Eagles in lowland and mountain habitats of East-Hungary between 1989 and 2006

1. ábra A fészkelő párok számának (a), a legközelebbi szomszéd távolságnak (b) és a nem-adult párok gyakoriságának (c) változása a kelet-magyarországi parlagi sas állományban a hegyvidéki (fekete négyzet) és síkvidéki (fehér kör) élőhelyeken 1989 és 2006 között 


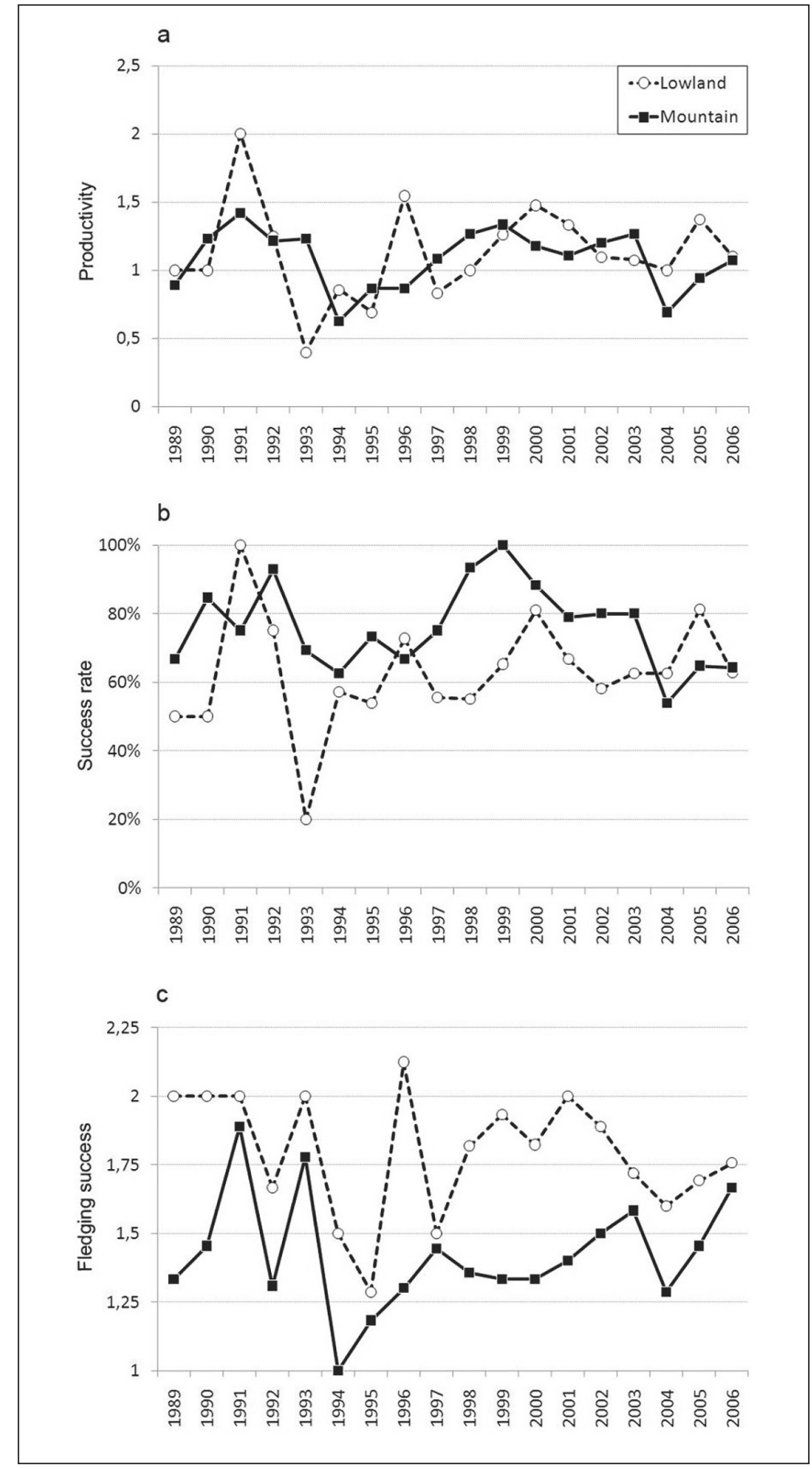

Figure 2. Changes in productivity (a), success rate (b) and fledging success (c) of Eastern Imperial Eagles in lowland and mountain habitats of East-Hungary between 1989 and 2006

2. ábra A produktivitás (a), a sikerességi arány (b) és a kirepülési siker (c) változása a kelet-magyarországi parlagi sas állományban a hegyvidéki (fekete négyzet) és síkvidéki (fehér kör) élőhelyeken 1989 és 2006 között 


\begin{tabular}{|l|c|c|c|c|c|c|}
\hline & \multicolumn{2}{|c|}{ Mountain } & \multicolumn{2}{c|}{ Lowland } & & \\
\cline { 2 - 7 } & $\mathrm{n}$ & mean \pm SD & $\mathrm{n}$ & mean \pm SD & $t$ & $P$ \\
\hline Productivity & 20 & $-0.098 \pm 0.371$ & 51 & $-0.005 \pm 0.466$ & 0.805 & 0.424 \\
\hline Success rate & 20 & $0.006 \pm 0.233$ & 51 & $-0.043 \pm 0.210$ & -0.851 & 0.398 \\
\hline Fledging success & 19 & $-0.162 \pm 0.306$ & 50 & $0.086 \pm 0.390$ & 2.494 & $0.015^{*}$ \\
\hline
\end{tabular}

* significant at $P=0.05$ level

Table 1. Comparison of breeding success variables between the territories of the two habitat types. (Productivity $=$ the number of fledglings per a nesting pair; Success rate $=$ the frequency of nesting pairs that fledged at least one chick; Fledging success $=$ the number of fledglings per successful nesting pairs)

1. táblázat A költési siker változók összehasonlítása a két élőhelyen. (Produktivitás = kirepült fiókák száma / fészkelő párok száma; Sikerességi arány = azon fészkelő párok aránya, amelyek legalább egy fiókát sikeresen kireptettek; Kirepülési siker = kirepült fiókák száma / sikeres párok száma)

\begin{tabular}{|c|c|c|c|c|c|c|}
\hline & \multicolumn{2}{|r|}{ Adult } & \multicolumn{2}{|r|}{ Non-adult } & \multirow[b]{2}{*}{$t$} & \multirow[b]{2}{*}{$P$} \\
\hline & $n$ & mean $\pm S D$ & $\mathrm{n}$ & mean $\pm S D$ & & \\
\hline Productivity & 46 & $0.107 \pm 0.602$ & 46 & $-0.162 \pm 0.756$ & -1.995 & 0.052 \\
\hline Success rate & 46 & $0.104 \pm 0.279$ & 46 & $-0.115 \pm 0.387$ & -3.257 & $0.002^{*}$ \\
\hline Fledging success & 35 & $-0.079 \pm 0.448$ & 35 & $0.009 \pm 0.435$ & 0.903 & 0.373 \\
\hline
\end{tabular}

* significant at $P=0.05$ level

Table 2. Pairwise comparison of breeding success variables of adult and non-adult pairs within the same territories. (Productivity = the number of fledglings per a nesting pair; Success rate $=$ the frequency of nesting pairs that fledged at least one chick; Fledging success $=$ the number of fledglings per successful nesting pairs)

2. táblázat A költési siker változók páros összehasonlítása az „adult" (két kiszíneződött madárból álló) és „nem-adult” (legalább egy átszíneződő madarat tartalmazó) párok között. (Produktivitás = kirepült fiókák száma / fészkelő párok száma; Sikerességi arány = azon fészkelő párok aránya, amelyek legalább egy fiókát sikeresen kireptettek; Kirepülési siker = kirepült fiókák száma / sikeres párok száma)

nificant correlation between NND and any of the breeding success variables (productivity: $r_{s}=-0.022, P=0.842$; success rate: $r_{s}=-0.056, P=0.601$; fledgling success: $r_{s}$ $=0.113, P=0.338)$. Moreover, as density increased in the lowland habitats during the study period, no changes were observed in any of the breeding success variables (see above). Therefore we assumed that there was no significant density-dependent effect of the studied parameters in the study period.

\section{Simultaneous effect of age and habitat}

Breeding success variables showed some difference both regarding habitat type and age of breeding birds in univariate comparisons without considering the possible simultaneous effects (Table 1 and Table 2). We also found significant rank correlations between the frequency of non-adult pairs and each of two breeding success variables of the territories (productivity: $r=-0.354, P=$ 0.002; success rate: $r_{s}=-0.337, P=0.004$ ), although fledgling success did not correlate significantly $\left(r_{s}=-1.102, P=0.406\right)$. Never- 


\begin{tabular}{|c|c|c|c|c|}
\hline & $\begin{array}{c}\text { Type III } \\
\text { Sum of Squares }\end{array}$ & Mean Square & $\boldsymbol{F}$ & $P$ \\
\hline \multicolumn{5}{|l|}{ Productivity } \\
\hline Corrected Model & 2.447 & 0.816 & 4.895 & $0.004 *$ \\
\hline Intercept & 0.617 & 0.617 & 3.702 & 0.059 \\
\hline Habitat & 0.002 & 0.002 & 0.01 & 0.922 \\
\hline Age & 2.308 & 2.308 & 13.853 & $<0.001 *$ \\
\hline Habitat $\times$ Age & 0.810 & 0.81 & 4.859 & $0.031 *$ \\
\hline \multicolumn{5}{|l|}{ Success rate } \\
\hline Corrected Model & 0.767 & 0.256 & 6.856 & $<0.001 *$ \\
\hline Intercept & 0.207 & 0.207 & 5.547 & $0.021 *$ \\
\hline Habitat & 0.152 & 0.152 & 4.074 & $0.048 *$ \\
\hline Age & 0.725 & 0.725 & 19.449 & $<0.001 *$ \\
\hline Habitat $\times$ Age & 0.383 & 0.383 & 10.275 & $0.002 *$ \\
\hline \multicolumn{5}{|l|}{ Fledging success } \\
\hline Corrected Model & 1.379 & 0.690 & 5.289 & $0.007^{*}$ \\
\hline Intercept & 0.090 & 0.090 & 0.692 & 0.409 \\
\hline Age & 0.531 & 0.531 & 4.071 & $0.048 *$ \\
\hline Habitat & 1.285 & 1.285 & 9.856 & $0.003 *$ \\
\hline Habitat $\times$ Age $* *$ & - & - & - & - \\
\hline
\end{tabular}

* significant at $P=0.05$ level $\quad$ ** interaction was not significant, therefore it was removed from the model

Table 3. Results of the Generalized Linear Models analysing the effects of habitat type and age of the breeding birds on breeding success variables

3. táblázat Az Általánosított Lineáris Modell (GLM) eredménye, amely az élőhely-típus és a költő madarak korának hatását mutatja a költési siker változókra

theless, the frequency of non-adult pairs differed significantly between the two habitat types $(22.1 \pm 26.3 \%$ in the mountains and $49.5 \pm 35.1 \%$ in lowlands; Mann-Whitney U-test, $\mathrm{Z}=-2.964, \mathrm{P}=0.003$ ), therefore the possible simultaneous effects were tested in a generalized linear model.

The linear models showed different results for the three breeding success variables (Table 3). We found that overall productivity was affected primarily by the age of the breeding pairs, but also by the interaction between habitat and age effects. Success rate was also primarily affected by the age of the pairs, although the habitat and interaction between the two effects were al- so significant. Finally habitat showed stronger effect on fledging success, but age of the pairs also had a significant effect.

\section{Discussion}

Our results revealed that habitat selection of Imperial Eagles in Hungary changed in the last two decades, causing an unexpected population growth and breeding area expansion. From their mountainous refugees Imperial Eagles expanded their original breeding areas in Hungary to the lowlands, which were most probably abandoned for at least one hundred years. Although presently 
the new breeding area, the Hungarian Great Plain, with its developed agriculture and dense system of settlements, seems to be suffering from high human disturbances, the reproductive success parameters suggested that this new breeding area offer high-quality breeding sites for the eagles.

Similarly to other studies (Steenhof 1983, Balbontín et al. 2003, Ferrer et al. 2003) we found a strong effect of age of breeding birds on reproductive success variables, i.e. nonadult pairs bred less successfully. Not surprisingly, in the newly-occupied areas nonadult eagles were more frequent than in the traditional mountainous areas and we found that age and habitat type had simultaneous effects on breeding success variables, as it was also shown on Bonelli's Eagles (Aquila fasciata) in Spain (Penteriani et al. 2003). We found that age-effect is more significant on success rate (i.e. the ratio of pairs that produce at least one chick), while habitat-effect was more evident on fledging success (i.e. the number of fledglings per productive pair). The overall productivity (i.e. number of fledglings per breeding pair) was affected primarily by the age of the pairs, but the interaction of age and habitat type had also significant effect. We suppose that better feeding possibilities (closer foraging areas and larger prey density) could explain the higher fledging success in the lowlands. We also predicted that pairs inhabiting lowland agricultural areas suffer more from human disturbance resulting in a lower success rate, but even if this trend was observable it had significant effect only in interaction with the age of the pairs. This interaction is probably caused by inexperienced non-adult pairs, which are threatened by the higher level of lowland disturbance, while experienced adult pairs can breed with similar success as in the undisturbed mountains.
Although the exact causes, which started the population expansion in the Imperial Eagles in Hungary are not known, our study revealed that freshly occupied lowland habitats can be more productive than traditional mountainous ones. Such a process is surprising in an expanding population as most studies report that if a population is not saturated the best habitats are occupied first (Newton 1979, Sergio \& Newton 2003). Moreover the population size of Brown Hare (Lepus europaeus), the main prey species of Imperial Eagles is Hungary (Horváth et al. 2010), has been continuously declining since the 1960's in parallel with the intensification of agriculture (Báldi \& Faragó 2007). Therefore the colonization of the lowlands is most probably not caused by any recent increased availability of food supply, but by an increasing population size in the original habitats. After the population in the mountains started to increase and the level of persecution decreased in the lowlands, some eagles tried to settle in these new habitats. The appearance of these first inventory pairs was probably the most important step in the expansion, as the high natal philopatry of the species (González et al. 2006b) hinders the sudden colonization of habitats far from the original breeding distribution area. The huge and well visible nests and territorial behaviour of conspecifics indicate, that lowland agricultural areas can be also suitable habitats for them (Newton 1979). During the last two decades these freshly colonized habitats proved to be even more suitable for the species, than the traditional mountainous forests, and since large agricultural regions of the Hungarian Plain are still not inhabited by the species we expect further expansion in the near future. 


\section{Acknowledgement}

Population survey was undertaken by the members of the Hungarian Imperial Eagle Working Group, which is operated by MME BirdLife Hungary and relevant national park directorates. We are especially grateful to Iván Demeter, Imre Tóth and Tamás Zalai for their grate help in the field work. We thank Miguel Ferrer, Vincenzo Penteriani and Maria Mar Delgado for their valu-

\section{References}

Bagyura, J., Szitta, T., Haraszthy, L., Firmánszky, G., Viszló, L., Kovács, A., Demeter, I. \& Horváth, M. 2002. Population increase of Imperial Eagle (Aquila heliaca) in Hungary between 1980 and 2000. Aquila 107-108: 133-144.

Balbontín, J., Penteriani, V. \& Ferrer, M. 2003. Variations in the age of mates as an early warning signal of changes in population trends? The case of Bonelli's Eagle in Andalusia. - Biological Conservation 109: 417-423. DOI: http://dx.doi.org/10.1016/ S0006-3207(02)00168-4

Báldi, A. \& Faragó, S. 2007. Long-term changes of farmland game populations in a post-socialist country (Hungary). - Agriculture, Ecosystems and Environment 118: 307-311. DOI: http://dx.doi. org/10.1016/j.agee.2006.05.021

BirdLife International 2013. Imperial Eagle Aquila heliaca. - In: IUCN Red List of Threatened Species. -Version 2013.2 (IUCN, 2013). (www.iucnredlist. org)

Cody, M. L. (ed.) 1985. Habitat selection in birds. Academic Press, Orlando, pp. 558

Cowie, R. J. 1977. Optimal foraging in Great Tit (Parus major). - Nature 268: 137-139. DOI: http://dx.doi. org/10.1038/268137a0

Del Hoyo J., Elliot, A. \& Sargatal, J. 1995. Handbook of the Birds of the World. Vol. 2. Falconiformes to Galliformes. - Barcelona, Lynx Edicions, pp. 638

Ferrer, M. \& Bisson, I. 2003. Age and territory-quality effects on fecundity in the Spanish Imperial Eagle (Aquila adalberti). - The Auk 120(1): 180-186. DOI: http://dx.doi.org/10.1642/0004-8038(2003)1 20[0180:AATEOF]2.0.CO;2

Ferrer, M. \& Donazar, J. A. 1996. Density-dependent fecundity by habitat heterogeneity in an increasing population of Spanish Imperial Eagles. - Ecology 77(1): 69-74. DOI: http://dx.doi. org/10.2307/2265655 able suggestions in planning the study. Péter Kabai helped to improve the quality of the manuscript, and József Vuts made the language correction. The Hungarian Imperial Eagle conservation programme was funded by the European Commission's LIFE-Nature programme (LIFE02NAT/H/8627) between 2002 and 2005. M.H. was granted by the Spanish Ministry of Education and Science and Doñana Biological Station (ICTSRBD 2007-2008).

Ferrer, M., Otalora, F. \& García-Ruiz, J. M. 2004. Density-dependent age of first reproduction as a buffer affecting persistence of small populations. - Ecological Applications 14(2): 616-624. DOI: http:// dx.doi.org/10.1890/02-5361

Ferrer, M., Newton, I. \& Casado, E. 2006. How to test different density-dependent fecundity hypotheses in an increasing or stable population. - Journal of Animal Ecology 75(1): 111-117. DOI: http://dx. doi.org/ 10.1111/j.1365-2656.2005.01026.x

Ferrer, M. \& Penteriani, V. 2008. Non-independence of demographic parameters: positive density-dependent fecundity in eagles. - Journal of Applied Ecology 45: 1453-1459. DOI: http://dx.doi. org/10.1111/j.1365-2664.2008.01497.x

Forsman, D. 1999. The raptors of Europe and the Middle East: A handbook of field identification. - T \& AD Poyser, London, pp. 589

González, L. M., Arroyo, B. E., Margalida, A., Sanchez, R. \& Oria, J. 2006a Effect of human activities on the behaviour of breeding Spanish Imperial Eagles (Aquila adalberti): management implications for the conservation of a threatened species. - Animal Conservation 9: 85-93. DOI: http://dx.doi. org/10.1111/j.1469-1795.2005.00016.x

González, L. M., Oria, J., Margalida, A., Sánchez, R., Prada, L., Caldera, J., Aranda, A. \& Molina, J. I. 2006b Effective natal dispersal and age of maturity in the threatened Spanish Imperial Eagle Aquila adalberti: conservation implications. Bird Study 53(3): 285-293. DOI: http://dx.doi. org/10.1080/00063650609461444

Haraszthy, L., Bagyura, J., Szitta, T., Petrovics, Z. \& Viszló, L. 1996. Biology, Status and Conservation of the Imperial Eagle Aquila heliaca in Hungary. In: Meyburg, B-U. \& Chancellor, R. D. (eds.) Eagle Studies. - World Working Group on Birds of Prey (WWGBP), Berlin, London \& Paris, pp. 425-427. 
Hildén, O. 1965. Habitat selection in birds. A review. Annales Zoologici Fennici 2: 53-75.

Horváth, M., Szitta, T., Firmánszky, G., Solti, B., Kovács, A. \& Moskát, C. 2010. Spatial variation in prey composition and its possible effect on reproductive success in an expanding Eastern Imperial Eagle (Aquila heliaca) population. - Acta Zoologica Academiae Scientiarum Hungaricae 56: 187-200.

Horváth, M., Szitta, T., Fatér, I., Kovács, A., Demeter, I., Firmánszky, G. \& Bagyura, J. 2011. Population dynamics of the Eastern Imperial Eagle (Aquila heliaca) in Hungary between 2001 and 2009. - Acta Zoologica Bulgarica (Suppl. 3): 61-70.

Janes, S. W. 1985. Habitat selection in raptorial birds. - In: Cody, M. L. (ed.) Habitat selection in birds. Academic Press, Orlando, pp. 159-190.

Karyakin, I. V., Nikolenko, E. N., Levin, A. S. \& Kovalenko, A. V. 2008. Imperial Eagle in Russia and Kazakhstan: population status and trends. - Raptors Conservation 14: 18-27.

Katzner, T. E., Bragin, E. A., Knick, S. T. \& Smith, A. T. 2003. Coexistence in a multispecies assemblage of eagles in Central Asia. - The Condor 105: 538551. DOI: http://dx.doi.org/10.1650/7140

Katzner, T. E., Bragin, E. A. \& Milner-Guland, E. J. 2006. Modelling populations of long-lived birds of prey for conservation: A study of Imperial Eagles (Aquila heliaca) in Kazakhstan. - Biological Conservation 132: 322-335. DOI: http://dx.doi. org/10.1016/j.biocon.2006.04.024

Krüger, O., Liversidge, R. \& Lindström, J. 2002. Statistical modelling of the population dynamics of a raptor community in a semi-desert environment. - Journal of Animal Ecology 71(4): 603-613. DOI: http://dx.doi.org/10.1046/j.13652656.2002.00626.x

López-López, P., García-Ripollés, C., Soutullo, A., Cadahía, L. \& Urios, V. 2007. Identifying potentially suitable nesting habitat for Golden Eagles applied to 'important bird areas' design. - Animal Conservation 10: 208-218. DOI: http://dx.doi. org/10.1111/j.1469-1795.2006.00089.x

Margalida, A., González, L. M., Sánchez, R., Oria, J., Prada, L., Caldera, J., Aranda, A. \& Molina, J. I. 2007. A long-term large-scale study of the breeding biology of the Spanish Imperial Eagle (Aquila adalberti). - Journal of Ornithology 148(3): 309322. DOI: http://dx.doi.org/10.1007/s10336-0070133-5

Newton, I., Marquiss, M., Weir, D. N. \& Moss, D. 1977. Spacing of Sparrowhawk nesting territories. - Journal of Animal Ecology 46: 425-441.

Newton, I. 1979. Population ecology of raptors. - T \& AD Poyser, Berkhamsted, pp. 399
Penteriani, V., Balbontín, J. \& Ferrer, M. 2003. Simultaneous effects of age and territory quality on fecundity in Bonelli's Eagle Hieraaetus fasciatus. - Ibis 145: E77-E82. DOI: http://dx.doi.org/10.1046/ j.1474-919X.2003.00159.x

Penteriani, V., Fortuna, M. A., Melián, C. J., Otalora, F. \& Ferrer, M. 2006. Can prey behaviour induce spatially synchronic aggregation of solitary predators? - Oikos 113: 497-505. DOI: http://dx.doi. org/10.1111/j.0030-1299.2006.14547.x

Petrov, T., Iankov, P., Darakchiev, A., Nikolov, K., Michev, T., Profirov, L. \& Milchev, B. 1996. Status of the Imperial Eagle Aquila heliaca in Bulgaria in the period between 1890 and 1993. - In: Meyburg, B-U. \& Chancellor, R. D. (eds.) Eagle Studies - World Working Group on Birds of Prey (WWGBP), Berlin, London \& Paris, pp. 429-434.

Sergio, F. \& Newton, I. 2003. Occupancy as a measure of territory quality. - Journal of Animal Ecology 72(5): 857-865. DOI: http://dx.doi.org/10.1046/ j.1365-2656.2003.00758.x

Sergio, F., Pedrini, P., Rizzolli, F. \& Marchesi, L. 2006. Adaptive range selection by Golden Eagles in a changing landscape: A multiple modelling approach. - Biological Conservation 133(1): 32-41. DOI: http://dx.doi.org/10.1016/j.biocon.2006.05.015

Sergio, F., Marchesi, L., Pedrini, P. \& Penteriani, V. 2007. Coexistence of a generalist owl with its intraguild predator: distance-sensitive or habitatmediated avoidance? - Animal Behaviour 74: 1607-1616. DOI: http://dx.doi.org/10.1016/j.anbehav.2006.10.022

Steenhof, K. 1987. Assessing raptor reproductive success and productivity. - In: Giron Pendleton, B. A., Millsap, B. A., Cline, K. W. \& Bird, D. M. (eds.) Raptor management techniques manual. National Wildlife Federation, Washington D.C., pp. 157-170.

Steenhof, K., Kochert, M. N. \& Doremus, J. H. 1983. Nesting of subadult Golden Eagles in Southwestern Idaho. - The Auk 100: 743-746.

Tapia, L., Domínguez, J. \& Rodríguez, L. 2008. Hunting habitat preferences of raptors in a mountainous area (northwestern Spain). - Polish Journal of Ecology 56: 323-333.

Vasvári, M. 1938. Der Verbreitung und Oekologie des Kaiseradlers (Aquila heliaca Sav.) [The distribution and ecology of the Imperial Eagle]. - In: Festschrift zum 60. Geburtstage von Professor Dr. Embrik Strand. Riga, Vol. 5., pp. 290-317. (in German with English Summary)

Wiens, J. A. 1989. The ecology of bird communities. Vols. 1-2. - Cambridge University Press, Cambridge, pp. 543 